${ }^{9}$ Robyn, C, et al, in Prolactin and Human Reproduction: Proceedings of Serono Symposia, vol 11, eds P G Crosignani and C Robyn, p 71 . London, Academic Press, 1977.

10 Thorner, M O, et al, British Medical fournal, 1974, 2, 419

1 Thorner, M O, et al, British Medical fournal, 1975, 4, 694

12 Nokin, J, et al, British Medical fournal, 1972, 3, 561.

13 McNeilly, A S, et al, fournal of Endocrinology, 1974, 61, 301.

14 Noel, G L, et al, Journal of Clinical Endocrinology and Metabolism, 1972, 35,840 .

${ }^{15}$ Noel, G L, Suh, H K, and Frantz, A G, Fourth International Congress of Endocrinology, abstract No 256, ed R O Scow. Amsterdam, Excerpta Medica, 1972

${ }^{16}$ Kolodny, R C, Jacobs, L S, and Daughaday, W H, Nature, 1972, 238, 284.

17 Kann, G and Martinet, J, Nature, 1975, 257, 63.

18 Noel, G L, Suh, H K, and Frantz, A G, Fournal of Clinical Endocrinology and Metabolism, 1974, 38, 413.

${ }^{19}$ Contesso, G P, Ceriani, R L, and Nataf, B M, Fourth International Congress of Endocrinology, abstract No 265, ed R O Scow. Amsterdam, Excerpta Medica, 1972.

${ }^{20}$ Cooke, I, et al, Postgraduate Medical fournal, 1976, 52, suppl 1, 75 .

21 McNeilly, A S, Postgraduate Medical fournal, 1975, 51, 231.

22.2 Thorner, M O, Clinics in Endocrinology and Metabolism, 1977, 6, 201.

23 Ben-David, M, Danon, A, and Sulman, F G, Journal of Endocrinology, 1971, 51, 719 .

24 Thorner, M O, and Besser, G M, in Prolactin and Human Reproduction: Proceedings of Serono Symposia, vol 11, eds P G Crosignani and C Robyn, p 285. London, Academic Press, 1977.

25.5 Glass, M R, et al, British Medical fournal, 1975, 3, 274.

26 Bassi, F, et al, Clinical Endocrinology, 1977, 6, 5 .

27 Horrobin, D F, et al, Lancet, 1971, 2, 352.

${ }^{2 *}$ Griffith, R W, IRCS, 1974, 2, 1661.

\section{The time and place for digestive enzymes}

According to the simple scheme of digestion taught in the early stages of medical school physiology the pancreas secretes an active enzyme, trypsinogen, which is converted into the potent proteolytic enzyme trypsin within the intestinal lumen. Why this is so, and how the process occurs, are less often considered.

One obvious and desirable reason for the two-step mechanism is to prevent the pancreas from digesting itself. Another possible advantage is that this proteolytic mechanism may be activated at a precise time or in a particular part of the gut, as determined by the activating mechanism. It might also be possible for the degree of activation, as well as the time and place, to be changed if metabolic requirements or other aspects of digestion were altered.

Interest in the mechanism by which trypsinogen becomes active trypsin has recently been revived. The change is brought about by the enzyme enterokinase, a glycoprotein found in the small intestine both in duodenal juice and bound to the brush-border membrane. Some workers have thought that enterokinase may originate in goblet cells or Brunner's glands, ${ }^{1-3}$ but it cannot be shown there by immunological methods, ${ }^{4}$ and the weight of evidence indicates that it arises in those busy little structures, the microvilli or brush border of the intestinal epithelial cells (enterocytes). ${ }^{j-8}$ As with other digestive enzymes, ${ }^{9}$ the amount of enterokinase within the cell seems to increase as the enterocyte migrates from crypt to villus tip, but enterokinase differs from other enzymes in that its concentration is not reduced in the mucosa of patients with coeliac disease. ${ }^{2-3}$

More interesting, and potentially more important, is the apparent confinement of the enzyme to a very short segment of the intestine-the duodenum and first $15 \mathrm{~cm}$ of jejunum. ${ }^{4}$ Enterocytes of this segment are unlikely to be intrinsically different from those in the remainder of the gut, and Hermon-
Taylor and his colleagues ${ }^{4}$ suggest that enterokinase synthesis may be triggered off by changes in luminal concentrations of other digestive substances. Trypsin, chymotrypsin, or bileacids, which release enterokinase from microvilli, are all possible agents. ${ }^{610}$ Slight support for this hypothesis comes from the observation of enterokinase activity in a segment of mid-jejunum anastomosed to the biliary and pancreatic ducts after a Whipple's operation. ${ }^{4}$

Inevitably these observations raise as many questions as they tentatively answer. What happens to enterokinase when there is no trypsin secretion? Is trypsin output affected by enterokinase secretion? To what hormonal stimuli is enterokinase susceptible? Severe enterokinase deficiency has been reported in an infant, but do lesser degrees of deficiency occur, either primarily or secondary to other gut disease? Why are normal amounts of enterokinase present in the atrophic jejunum? There still remains much to fascinate us as the subtle integration of the digestive process is revealed and as we come to realise the complexity and interdependence of the feedback mechanisms that control normal digestion, absorption, and nutrition.

\author{
${ }^{1}$ Eggermont, E, et al, Lancet, 1971, 2, 369. \\ 2 Rutgeerts, L, Tytgat, G, and Eggermont, E, Gastroenterology, 1972, \\ $63,381$. \\ ${ }^{3}$ Woodley, J F, and Keane, R, Gut, 1972, 13, 900 \\ ${ }^{4}$ Hermon-Taylor, J, et al, Gut, 1977, 18, 259. \\ Lobley, R W, and Holmes, R, Gut, 1970, 11, 1059 \\ "Hadorn, B, et al, Lancet, 1971, 1, 165. \\ Nordström, C, and Dahlqvist, A, Lancet, 1971, 1, 1185. \\ Schneider, R, Troesch, V, and Hadorn, B, Biologie et Gastroenterologic, \\ $1975,8,11$ \\ ${ }^{9}$ Nordström, C, and Dahlquist, A, Scandinavian fournal of Gastroenterology, \\ 1973, 8, 407. \\ 11) Nordström, C, Biochimica et Biophysica Acta, 1972, 289, 367. \\ $"$ Hadorn, B, et al, Lancet, 1969, 1, 812.
}

\section{Recovery patterns and prognosis in aphasia}

Quantitative and long-term studies of recovery of function are remarkably rare, so that the recent investigation of recovery patterns in aphasia in a large and relatively unselected group of patients by Kertesz and $\mathrm{McCabe}^{1}$ is both welcome and informative. The practical and methodological problems of studies of this kind are daunting-taxonomy, for examplebut Kertesz and McCabe had no illusions on this score: they regarded the conventional classification they used (Broca's, Wernicke's anomic, conduction, and global aphasia) as a simple tool of measurement that might not be accurate or sensitive enough to provide a reliable prognosis for the individual case. Their caution was more than justified in view of the changing pattern of linguistic deficit over time.

How, indeed, can long-term recovery most appropriately be measured? Kertesz and McCabe used modified subtests of the Boston aphasia examination, including fluency (number and type of utterances), comprehension (responses to questions and instructions), and repetition (of words and sentences). Some of their patients were tested repeatedly months and in some cases several years after onset. The resulting graphs presented a variety of patterns, but a fair proportion showed the expected curve, most improvement occurring ${ }^{1-5}$ within three months. The curiously flat graphs of some patients could probably be related to the fact that most of this 